Gesnerus 52 (1995) 203-204

\title{
Contents
}

Editorial:Pour l'anniversaire de Jean Starobinski. Bibliographie des travaux de Jean Starobinski en histoire de la médecine. Par V. Barras [Jean Starobinski, Anniversary and Bibliography of his Medico-historical

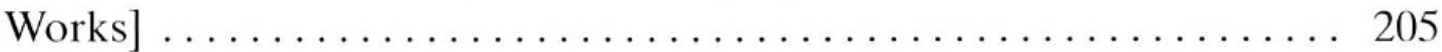

Hans Wolfgang Bellwinkel: Dürrenmatt und die Naturwissenschaften [Dürrenmatt and the Sciences] . . . . . . . . . . . . . . . . . . 209

Cay-Rüdiger Prüll: Die Grundkonzepte der Pathologie in Deutschland von 1858 bis heute und der Fortschrittsbegriff in der Medizin [Basic Concepts in German Pathology after 1858 and the Problem of Progress

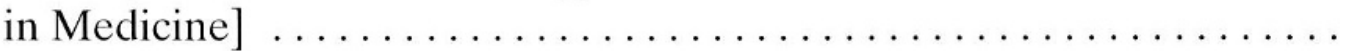

René Raggenbass: La fièvre bilieuse hémoglobinurique: un épisode français tiré d'une recherche d'Alexandre Yersin [Blackwater Fever: A French Episode Based on an Investigation by Alexander Yersin] . .

Nicolò Nicoli Aldini: The First Billroth II Gastric Resection as Reported by an Italian Medical Journal . . . . . . . . . . . . . . . . . . . . 290

Mikkel Borch-Jacobsen und Sonu Shamdasani: Ein Dokument: Das Problem der Willensfreiheit und die Psychoanalyse. Eine psychoanalytische Schrift des «Wolfsmanns» [A Document: The Problem of Free Will in Psychanalysis. A Psychanalytic Text of the Wolfman] . . . . . . . .

\section{Short Communications:}

Franz Daxecker und Annemarie Broucek: Eine Darstellung der hl. Ottilie mit Lesesteinen [A Representation of Saint Ottilia with Reading Stones $]$. . . . . . . . . . . . . . . . . . . . . . 319 
Short Communications:

Christoph Mörgeli: Wilhelm Conrad Roentgen and Switzerland. Exhibition in the Museum of the History of Medicine of the University of Zurich, May 18th to December 17th, 1995

News and Activities

Book Reviews ................................ 336

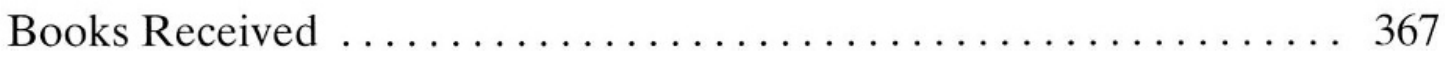

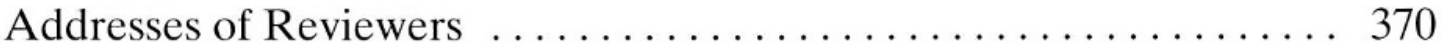

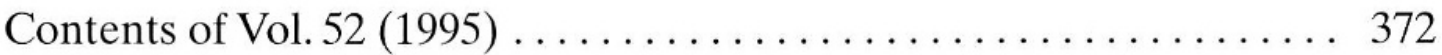

